\title{
Victor Brauner's Writing in/at Work: Dada and Surrealist Inventions of a Picto-poet
}

\section{Camille Morando}

The importance and place of writing in the work of the artist Victor Brauner (19031966) were made clearly evident by the 2005 publication of a significant portion of the Victor Brauner archives held at the Bibliothèque Kandinsky in the Musée national d'art moderne-Centre de création industrielle at the Centre Pompidou in Paris. ${ }^{1}$ An examination of the painter's use of the written word can shed new light on his visual work by tracing, from the beginning of his career, a little-known body of writing as well as Brauner's practice of incorporating writing into his paintings. Thus, this essay proposes to show Brauner's writing at work/in his work.*

The artist left Romania and settled permanently in France in 1938, but his Romanian sources and memories can be read beneath the surface and sometimes even more explicitly in his work. During his first two stays in Paris (1925-1927 and 1930-1935), Brauner had the opportunity to frequent Romanian exiles such as Ilarie Voronca, Benjamin Fondane, Claude Sernet, Constantin Brancusi, and Jacques Hérold; after joining the surrealist movement in 1933, Brauner became the primary connection to Paris for the surrealist group of Bucharest, in particular for Gherasim Luca and Gellu Naum (Yaari). Brauner's correspondence with his family and his

\footnotetext{
* For illustrations of works discussed that are in the collections of the Mnam-Cci, Centre Pompidou, see that institution's online collection:

$<$ http://collection.centrepompidou.fr/Navigart/index.php?db=minter\&qs=1>

1 Victor Brauner, écrits et correspondances 1938-1948. Le Fonds d'archives Victor Brauner was left to the French State by his wife Jacqueline in 1984, and became part of the public collections in 1986. See Patry, "La Publication des archives de Victor Brauner." The inventory of the Brauner archives can be accessed online at:

http://bibliothequekandinsky.centrepompidou.fr. We would like to extend warm thanks to our colleagues at the Bibliothèque Kandinsky: Véronique Borgeaud and Sonia Descamps, as well as Didier Schulmann (Director) and the Musée national d'art moderne-Centre de création industrielle (Mnam-Cci).
}

Dada/Surrealism No. 20 (2015) 
Romanian friends, including numerous letters received from Gherasim Luca and drawings addressed to him by Paul Păun, ${ }^{2}$ demonstrate Brauner's inherent connection to the country of his birth. These exchanges speak of the research pursued by their common friends during the 1920s in Bucharest, when Brauner participated actively in the Romanian avant-garde, particularly through his collaborations with Ilarie Voronca, Stephen Roll, Tristan Tzara, Saşa Pană, and others, for the journals $75 \mathrm{HP}$, Punct, Integral, and Unu. References to Romania and his origins are also found in his writings, in his library as it has come down to us, and in an abundant collection of photographs. ${ }^{3}$

Brauner's evolution took place freely and independently of his Romanian friends. An examination of his writings reveals that his poetic and linguistic transition from Romanian to French led to neologisms and wondrous inventions. While his visual art attests to his joining forces with Breton's surrealism in 1933, the lesser-known impact of the Dada spirit continued to be felt in his pictorial and literary inventions. Promenade 4 (1941), the only work of fiction written by the painter, forms a synthesis of his aspirations concerning alchemy and his surrealist dream research.

From the beginning, the presence of writing in Brauner's work reveals that it is intrinsic to this major artist's output. Motifs like the decapitated head or the enucleated eye return again and again like an obsession, haunting his paintings and his writings, like the sign of his incessant questions concerning the notion of identity and his desire to attain universality. And between 1938 and 1948, in addition to his own writings and personal correspondence in which he recorded and theorized his plastic inventions, Victor Brauner created a personal language through his wax paintings and his "objets de contre-envoûtement" (counter-spell objects), both of which generally integrate writing into the visual space. The conditions of daily life that gripped him also surface in his work, especially during the terrible years of war and privation. Exploring different subjects and genres, "picto-poet" 5 Victor Brauner left a distinct imprint on the artistic history of the 1930s and 1940s, a period marked by surrealism and war.

2 Published in Brauner, Paris, 2005.

3 In the exhibition catalogue edited by Didier Semin, Victor Brauner dans les collections $d u$ Musée national d'art moderne (hereafter cited as Semin, 1996) may be found the inventories of the Archives (p. 118-20), the photographic collection (p. 123) and Brauner's library (p. 124137).

4 See my article, "'Térapeutique [sic] de démoralisation ou contre inspiration' chez Victor Brauner." This essay focuses on the writing of this work of fiction developed in an altered state of consciousness during the war.

5 Brauner always used the spelling poëte. Pictopoetry will be defined later in this article. 


\section{A Painter's Vocation: Origins and Sources (1903-1938)}

Victor Brauner's singular, personal, and polymorphous work alluded to the world of the imaginary throughout his years of artistic production - a world which would be roughed up, invaded, and enriched by his sharp lucidity toward all things surrounding him, and by an insatiable curiosity toward other civilizations and fantastic universes. The artist, painter, and "picto-poet" would always embody an anti-conformism as political as it was aesthetic, which would contribute to his decision to leave Romania permanently for France in 1938.

Born in Piatra Neamț in Moldavia (in northeast Romania), Brauner and his family emigrated to Hamburg, Germany (1907-1910), returned to Piatra Neamț, then left for Vienna (1912-1914) ${ }^{6}$ before settling in Bucharest. Brauner recalled vivid moments of his childhood in a long prose poem titled "Mémoires d'un borgne"7 ("Memories of a one-eyed man"), written on 11 February 1945. The poem evokes the poverty of the peasants and the May 1907 riots in Moldavia followed by a bloody repression (which precipitated the Brauner family's flight to Hamburg), as well as the appearance of Halley's comet on 18 May, 1910, announced as heralding the end of the world. ${ }^{8}$

From a young age, Brauner desired above all to become a painter: self-taught, he began to paint in 1916, having built his own easel out of sticks. Frequenting the Bellu cemetery in Bucharest, Brauner was fascinated by the inscriptions on the tombstones and by the mausoleum of poet Iulia Haşdeu, ${ }^{9}$ daughter of the writer Bogdan Petriceuci Hașdeu, who, according to legend, communicated with Iulia using spiritualist practices. Brauner confided that, still a child, he also remembered his father, passionate about spiritualism, organizing hypnosis sessions with famous mediums in order to communicate with spirits in the beyond. ${ }^{10}$ Years later, this taste for magic and mystery prompted Brauner to initiate himself into tarot and the Kabbalah.

6 Brauner's knowledge of German dates from this period.

7 The poem was written in the notebook with black cover (1942-1945), published in Brauner, Paris, 200597.

8 Brauner described these events in the blue notebook (1960), Fonds Victor Brauner, Paris, Bibliothèque Kandinsky, Mnam-Cci, Centre Pompidou, inv. 8818-1089.

9 Iulia Hașdeu (1869-1888) studied at the Sorbonne in Paris. Her work in French and Romanian was published in Paris in 1889-1890. Margaret Montagne notes that Brauner used the motif of Iulia Haşdeu's mausoleum in one painting (without specifying which) dating from 1918 and in several drawings, such as Sans titre (1942); see Victor Brauner: Surrealist Hieroglyphs 45 and fig. 45.

10 See "Entretien avec Max-Pol Fouchet," in the program Terre des Arts, 1961, cited in Alexandrian, "Victor Brauner" 33 and Alexandrian, Victor Brauner 25. See also Montagne 113, where Brauner's father is described by Theodor, the brother of the painter, as "poète, socialiste et théosophe" 'poet, socialist and theosopher.' 
In 1919, Brauner enrolled at the Beaux-arts school in Bucharest. During a vacation at Fălticeni, Moldavia in 1921, he was fascinated by the behavior of a somnambulist, who would become a recurring motif in his work. Around 1922, he traveled to Balcik, Bulgaria on the shores of the Black Sea, along with other students from the beaux-arts school. ${ }^{11}$ In the tradition of Romanian painters wishing to break with academism and paint en plein air, Brauner tried his hand at peinture sur le motif: influenced by Cézanne, he composed landscapes in luminous colors and geometric forms. ${ }^{12}$ Some of his canvases "nous laissent déjà entrevoir son futur cheminement vers un art 'non rétinien'” 'already give us a glimpse of his future path toward a "non retinal" art'), to use Marina Vanci-Perahim's Duchampinspired term ("Victor Brauner: Les Débuts" 39). ${ }^{13}$ The deserted landscapes tend also to move away from mimesis, subtly evoking (despite the solar colors of certain landscapes) a feeling of strangeness and desolation, which will grow more pointed in his paintings of 1923. ${ }^{14}$ The stylized figures and their hieratic poses, also inspired by popular imagery, combine with simplified forms and an undulating geometrization approaching cubo-futurism. Refusing to bend to the academism of his coursework, Brauner was expelled from the Beaux-arts school ${ }^{15}$ for misbehavior and anti-conformist painting.

It is probably at this time that the young painter took on a project ${ }^{16}$ for an

11 See Marina Vanci-Perahim, "Victor Brauner: Les débuts" 38. This text relates in part to Vanci-Perahim's "Victor Brauner en Roumanie."

12 Like the oldest paintings: Cat. ${ }^{\circ} 1$, Peisaj din Balcik I, 1922-24, and Cat. n'2, Peisaj din Balcik II, 1920, preserved in Bucharest by the Federation of Jewish Communities (reproduced in Victor Brauner: Surrealist Hierogylphs 68-69), and Paysage à Balcik, circa 1922, Lot $\mathrm{n}^{\circ} 101$ (reproduced in Binoche and Giquello 32).

13 See Brauner, Balcik, 1922, reprod. In Victor Brauner: Un Monde magique 38.

14 The reproduced works date from 1923: Salomé, known only through a black-and-white photograph sent to M. Vanci-Perahim by Theodor Brauner, published in Stella 34; Bătrână intre două fete (the French title varies, either "Loth et ses filles," in Stella 34, or "Vieille femme entre deux jeunes filles," in Brauner, Houston, 2001, Cat. n³, p. 70) and Muncitoare (Worker) (cat. no. 4 in Victor Brauner: Surrealist Hieroglyphs 71) are preserved in Tulcea (Romania) at the art museum.

15 Vanci-Perahim alludes to a strike that took place in 1923 against the institution by the beaux-arts students, including Brauner, adding that "l'Académie libre," founded after this rebellion, would not keep the painter there for more than a year, at which point he decided to leave school permanently ("Victor Brauner: Les Débuts" 40).

16 Dating from late 1922-early 1923 to announce an evening lecture at the Insula Theater, founded by Fondane in 1922 and closed the following year. (Vanci-Perahim, "Victor Brauner en Roumanie" 42). 
Affiche de théàtre ${ }^{17}$ (theater poster), in which words mix with painting: in it, a text box announces a literary performance: "Il y aura / des mots" 'There will be / words read from works by Laforgue, Maeterlinck, and Goethe, as well as Romanian authors Brunea, Eminescu, Anton Pan, and Fundoianu (Fondane), writers of poetry and of both popular and critical literature. ${ }^{18}$ In the tradition of his 1923 canvases, Brauner represents a nude woman on either side of the box containing the text; above it are two grimacing masks. The contrasting colors and stylized figures confirm Brauner's break with academic figuration.

After meeting the poet Ilarie Voronca in 1923, ${ }^{19}$ Brauner established contact with the Romanian avant-garde milieux, where strong cubo-futurist and constructivist tendencies where exhibited. Beginning in 1924, along with Voronca, Marcel Janco, Ion Vinea, M.H. Maxy, Claude Sernet, and Stephan Roll, Brauner participated in the most politically and esthetically engaged editorial activities and expositions. ${ }^{20}$ Among these was the "Première Exposition internationale d'art plastique moderne en Roumanie" (First International Exhibition of Modern Plastic Art in Romania), held in Bucharest at Sala Mozart, Sindicatul Artelor Frumoase and presenting works of Jean Arp, Paul Klee, Hans Richter, Kurt Schwitters, Marcel Janco, M. H. Maxy, Constantin Brancusi, and others, in addition to "des masques et idoles d'Extrême-Orient" (masks and idols of the Far East) (Fauchereau 12-13). ${ }^{21}$

In October 1924, the same month that Breton published the first "Manifeste du surréalisme" in Paris, Brauner and Voronca created 75 HP, a journal that contained their common invention: "pictopoezie." Two paintings illustrating the process are reproduced in the magazine: words inscribed in the painting, stenciled or handwritten, marking the rhythm of the forms. Voronca and Brauner declare: "LA PICTOPOÈSIE [sic] . . . est le dernier-cri de l'heure actuelle. Tous les dandys doivent se tailler leurs babits [sic] d'après la coupe pictopoétique. La pictopoésie revivifie

17 V. Brauner, Affiche de théâtre, [1922-1923], pencil, gouache on brown paper, $126.2 \times 180 \mathrm{~cm}$, Paris, Mnam-Cci, Centre Pompidou. See Brauner's works in the Collection du Mnam-Cci, Centre Pompidou:

$<$ http://collection.centrepompidou.fr/Navigart/index.php?db=minter\&qs=1>.

18 See Lemny, "Projet d'une affiche de théâtre" 50.

19 Brauner executed ten drawings for the first collection of poetry by Voronca, Restriști. A copy of the book figures in the painter's library (Paris, Bibliothèque Kandinsly, Mnam-Cci, Fonds Victor Brauner, FB L 335) with an inscription by Voronca dated September 1931.

20 Brauner collaborated on the journals Integral (see Fonds Victor Brauner, Paris, Bibliothèque Kandinsky, Mnam-Cci, Centre Pompidou), Punct, and Contimporanul through his drawings.

21 The exhibition (30 November-30 December 1924) was organized by the journal Contimporanul, founded in 1922 by poets Ion Vinea and Marcel Janco (Iancu), and by the painter M.H. Maxy. Brauner exhibited four works titled "Construction," no doubt in a style similar to his geometric compositions published in $75 \mathrm{HP}$. 
tous les courents [sic] révélateurs d'art nouveau. LA PICTOPOÉSIE réalise enfin la vraie synthése [sic] des futurismes dadaismes constructivismes. . . PICTOPOÈsIE [SIC] TRIOMPHE SUR TOUT ENREGISTRE TOUT RÉALISE L'IMPOSSIBLE" ("Pictopoésie") 'PICTOPOETRY . . . is the newest thing of the hour. All dandys must tailor their clothes to the cut of pictopoetry. Pictopoetry revitalizes all the revelatory currents of the new art. PICTOPOETRY finally realizes the true synthesis of futurisms dadaisms constructivisms. ... PICTOPOETRY TRIUMPHS OVER ALL RECORDS ALL REALIZES THE IMPOSSIBLE.'

This artistic process, like the watchwords of $75 \mathrm{HP}$, is akin to the Dada spirit with its bombastic, declamatory tone, its humor and derision: "POUR COLLABORER A $75 \mathrm{HP}$ il faut: savoir bien danser / uriner sur tout / respecter ses parents / avoir souffert un / accident d'avion / ne pas faire de la litterature [sic] / avoir un certificat de bonne conduite / boire de l'acide sulfurique / connaitre la boxe se / décapiter deux fois / par semaine" (75 HP: p. 2 of cover) "TO COLLABORATE ON $75 \mathrm{HP}$ you must: really know how to dance / urinate on everything / respect your parents / have suffered an / airplane accident / not do literature / have a certificate of good behavior / drink sulfuric acid / know boxing / cut your head off twice / a week.' Advocating for the end of literature and a rejection of the status quo, $75 \mathrm{HP}$ claimed to be "l'unique groupe d'avantgarde [sic] de Roumanie" 'the only avantgarde [sic] group in Romania,' stating more specifically, "notre groupement compte parmi ses collaborateurs les meilleurs ecrivains [sic] et artistes du mouvement moderniste de tout le monde [sic]" (75 HP: p. 2 of cover) 'our band counts among its collaborators the best writers and artists the world over.' In her preface to the journal's 1993 reprint, Marina Vanci-Perahim emphasizes that $75 \mathrm{HP}$, with its "contenu explosif “' 'explosive contents,' its texts in Romanian, French, and German, and its "entrée fracassante dans l'arène artistique roumaine et internationale " (7) 'sensational entry onto the Romanian and international art scene' was above all a visual shock. It grabbed attention with novel typography, forcing the reader "à tourner sans cesse la revue pour suivre le parcours complexe de la mise en page" "to rotate the journal continually to follow the complex path of the print' of the texts, and imposing a "jeu alerte et stimulant" (8) 'alert and stimulating game.' This dynamic composition is accompanied by reproductions of works by Brauner, Marcel Janco, and M. H. Maxy, inspired "par la rigueur répétitive des surfaces géométriques de leur appartenance à l'univers constructiviste ou à l'esthétique promue par De Stijl” 'by the repetitive rigor of geometric surfaces of the constructivist universe or the aesthetic promoted by De Stijl.' If the artistic process of pictopoetic works recalls futurist compositions, if "l'exaltation de la vie moderne et de la dynamique citadine est un évident clin d'œil au futurisme" (17) 'the exaltation of modern life and the urban dynamic is an obvious wink to futurism,' the futurist taste for nationalism is absent from Brauner and Voronca's words. ${ }^{22}$ By creating syntheses of historical avant-gardes

22 See the preface by Marina Vanci-Perahim, 75 HP, 1993, p. 7-17. 
and recommending the reading of the European avant-gardist publications ("Bitte zu lesen"), they intended, through content and typography, to invent "un espace moderne, régi selon les rythmes nouveaux de l'univers machiniste . . . inventer une nouvelle sensibilité, un nouveau comportement" 'a modern space, governed by the new rhythms of the machinist world . . . to invent a new sensibility, a new behavior,' declaring themselves "décidément pour la liquidation systématique des anciens genres artistiques" (Vanci-Perahim, "Victor Brauner en Roumanie" 43) 'decidedly in favor of the systematic liquidation of former artistic genres.'

Brauner's first individual exhibition in Bucharest, from 25 October to 15 November 1924, was announced in $75 \mathrm{HP}$. In addition to two paintings titled Pictopoezia no. 5721 and Pictopoezia no. 384, a painting titled Constructie (1924), and three lino engravings including Portret în Linoleum with its constructivist design (that served as the exhibition poster), the journal published four canvases from the exhibition, which Voronca described as cubist, expressionist, and constructivist. In fact, the works were of radically opposing styles: on the one hand, paintings in an expressionist and dadaist vein, ${ }^{23}$ on the other, geometric compositions using cubist subjects (such as the portrait and still life). The diversity of styles in these early paintings attests to a writing at work that grapples with multiple inspirations in quest of a lost unity.

Despite announcing three issues to follow, $75 \mathrm{HP}$ would remain limited to a single issue. Yet it had a marked impact on the Romanian avant-garde groups and journals that followed, as well as on the international artistic scene, notably the nascent surrealism. Miguel Donville, one of the $75 \mathrm{HP}$ collaborators, left a copy at the Bureau de recherches surréalistes during a trip to Paris in November 1924 (Vance-Perahim, "75 HP" 7). This journal sealed the friendship between Voronca and Brauner and established the foundation of their future creative endeavors, which they continued along with others in the journals Punct, Integral, Urmuz, and Unu, confirming with this work the vitality of the Romanian avant-garde in Bucharest. ${ }^{24} 75 \mathrm{HP}$ also marked the beginning of the text-image connection formalized in Brauner's work by picto-poetry. The very term pictopoetry, itself an affirmation of freedom, would reappear in his correspondence later in 1948, when Brauner had to flee to Switzerland to escape the arrest of the growing number of

23 In particular, the one in which "deux personnages décapités jouent à se lancer leurs propres têtes" (Fauchereau 11) 'two decapitated characters are playing catch with their own heads.'

24 Punct (16 issues, 1924-1925) called itself "revistă de artă constructivistă internaţională” 'international constructivist journal,' born of $75 \mathrm{HP}$, "première revue ayant posé les bases d'un mouvement prêt à bouleverser l'amalgame crasseux de l'esprit roumain" 'the first review to establish the foundation of a movement prepared to upend the filthy mixture of ideas that is the Romanian mind'; Integral (15 issues, 1925-1928); Urmuz (5 issues in 1928); Unu (51 issues, 1928-1935). These journals can be consulted at the Bibliothèque Kandinsky, Mnam-Cci, Centre Pompidou, Paris, among other locations. 
Romanian nationals in France. ${ }^{25}$ In a letter addressed to Brauner, the surrealist artist Jean-Louis Bédouin alluded to this, calling his friend "Monsieur Picto-poet" and sending him a "Sésame cryptographique," a marvelous collage and drawing. In the imaginary passport he created for Brauner, Bédouin wrote: "Profession: Picto-poète." 26 This "passepartout cosmique" 27 'cosmic pass,' an omen for the hoped-for identity papers, reaffirmed Brauner's invention and the neologism that characterized the painter. As "picto-poet," Brauner restated in his reply the importance of the synthesis of writing and painting, and confirmed poetry as key to countering ostracisms of any order. ${ }^{28}$

During his first stay in Paris at the end of 1925, Brauner reunited with his Romanian friends (Ilarie Voronca, Benjamin Fondane, and Claude Sernet). Through them, he met Robert and Sonia Delaunay, Marc Chagall, and Man Ray, among others. He probably visited the "Peinture surréaliste" (Surrealist Painting) exhibition at the Gallery Pierre [Loeb] from 20 to 25 November 1925, which presented works by Jean Arp, Giorgio De Chirico, Max Ernst, Paul Klee, André Masson, Joan Mirò, Pablo Picasso, Man Ray, and Pierre Roy. The esthetic of these artists reinforced in Brauner his desire to continue questioning the notion of figuration and the status of the image in his work.

In February $1927^{29}$ Brauner returned to Bucharest, where he subsequently participated in the creation of Unu, a journal founded by Saşa Pană in April 1928, becoming one of its principal collaborators. Publishing, and thus introducing primarily surrealist texts, this review would play an important role as an intermediary between Paris and Bucharest. Brauner had returned to find his country impoverished, and watched the nationalist and anti-Semitic movement Garda de fier (the Iron Guard) (Legion of the Archangel Michael) flourish in

25 Brauner, who was in France illegally (he had false identity papers dated January 1941, reprod. in Victor Brauner, écrits et correspondances 373 (fig. 9)), would only acquire French nationality after multiple attempts to complete long administrative requirements, and with the encouragement of Jean Cassou and René Char, in June 1963 (Inv. 8818-1222, cited in Victor Brauner, écrits et correspondances 393).

26 Letter to Victor Brauner, [early July 1948] (Victor Brauner, écrits et correspondances 152), and "Sésame cryptographique" (346-47). On the line "Nom," Bédouin just lists the signature of the painter in 1948, in other words, " $\infty$, " the symbol for infinity, to which we will return later. On the line "Nationalité," Bédouin writes: "Subversive et boréale."

27 V. Brauner, letter to Jean-Louis Bédouin and Anne Vernier, 6 August 1948 (Victor Brauner, écrits et correspondances, p. 153).

28 In the aforementioned 1948 letter to Bédouin and Vernier, Brauner writes that he read an article in Combat (1-2 August 1948, p. 3), that condemned the recent arrest of Romanian nationals, including "des personnalités remarquables et connues depuis de longues années en France" (Victor Brauner, écrits et correspondances 153, note 36) 'remarkable personalities who have been well-known in France for years.'

29 Military service in the infantry until January 1929. 
Bucharest. That did not prevent him from engaging in intensive production of works with childlike motifs and rooted in popular art, painted in expressionist and dadaist style; or constructivist drawings "aux traits nets, des robots anthropomorphes qui font songer à Oskar Schlemmer ou Sandort Bortnyik" (Fauchereau 13) 'with clear traits, anthropomorphic robots recalling Oskar Schlemmer or Sandort Bortnyik.' Brauner had a second individual exhibition in 1927 (again at Sala Mozart); and in April 1929, he showed nine paintings and a series of sixty drawings titled "Introviziuni" (Introvisions) in the collective exhibition of sculpture, paintings, and drawings by the Grup de Artă nouă. With "Introviziuni," Brauner turned mimetic representation away from reality, wishing to "établir un nouveau point de vue sur la peinture" 30 'establish a new point of view on painting.' His work continued to decode the world of the imaginary, populated with animals and characters pierced by spears.

Brauner returned to Paris in May 1930 with his wife Margit Kosch and again frequented his Romanian friends (Fondane, ${ }^{31}$ Voronca, ${ }^{32}$ and Sernet). He also regularly visited the sculptor Constantin Brancusi, ${ }^{33}$ who entrusted him with taking photographs, one of which prophesized the accident to Brauner's eye. ${ }^{34} \mathrm{His}$ 1931 painting, Autoportrait, ${ }^{35}$ develops his premonition, representing the painter as enucleated: this "document" painting would occupy a symbolic place in his work and inscribe him, without his realizing it, in the tradition of objective chance so important to surrealism. Through Claude Sernet, in the spring of 1931 he met compatriot Jacques Hérold, ${ }^{36}$ with whom he frequented Brancusi's studio, where they also met Marcel Duchamp. When Brauner moved to rue du Moulin Vert, he became the neighbor and friend of Yves Tanguy, who introduced him to André Breton in 1933, a meeting that would be decisive for him. Eager to share an art renewed by the unconscious and the social role of the artist, Brauner joined the surrealists and immediately participated in their collective activities (exquisite corpses, publications, exhibitions). This connection with Breton would mark

30 Brauner, qtd. in Vanci-Perahim, "Victor Brauner en Roumanie" 46.

31 Morando, "Le Portrait."

32 Voronca and Fondane were the Paris editors for Integral.

33 In one of the films made by Brancusi (acquired by the French public collections in 2011) we see Victor Brauner and his wife Margit Kosch kissing in 1932; they were probably filmed in the sculptor's studio in Paris. (See AM 2011-F27, Paris, Mnam-CCi, Centre Pompidou). Thanks go to our colleagues Isabelle Daire and Philippe-Alain Michaud.

34 The photograph of a man bandaging the eyes of a woman across from the studio of Óscar Domínguez, boulevard Montparnasse. Photograph dated 1931, in Semin Victor Brauner, 1990, cit. p. 85 and reprod. p.82.

35 Oil on wood, $22 \times 16.2 \mathrm{~cm}$, Paris, Mnam-Cci, Centre Pompidou.

36 Like Brauner, he did miscellaneous work for Brancusi (Victor Brauner, écrits et correspondances 190). 
Brauner's break with Fondane and Brancusi, who refused to submit to Breton's authoritarianism, which Brauner would also reject a few years later. ${ }^{37}$

Breton wrote the preface to the catalogue for Brauner's first individual exhibition at the Pierre [Loeb] Gallery in December 1934, noting "l'imagination ... violemment déchaînée" and "le hiératique, le fantomatique et l'automatique" "the violently unleashed imagination . .." and 'the hieratic, ghostly, and automatic' nature of the characters "dans le cercle très inquiétant où l'apparition lutte crépusculairement avec l'apparence" 'in a very disturbing circle where apparition struggles in twilight manner with appearance.' Breton attested to the "plus haute valeur sociale" of the "peinture remarquablement libre de Brauner nous [faisant] assister" 'highest social value' of the 'remarkably free painting making us witness' the "combat singulier" 'singular combat' between "l'instinct sexuel" 'the sexual instinct' and "l'instinct de mort" ("Botte rose blanche" n. pag.) 'the death instinct.' Among the seventeen canvases exhibited, L'étrange cas de M.K. (The Strange Case of M.K.) (1933, Saint-Etienne, Musée d'Art moderne) introduced the Ubuesque figure of M.K., whose multiple representations in a story-board format used fictional writing the better to stigmatize the character who embodied the ridiculous stupidity of shameful power politics already leaning toward fascism.

Lacking financial resources, Brauner was forced to return to Romania in 1935. Still, he remained connected to the international art scene and his works were shown in the Dada and surrealist exhibitions in Tenerife, London, New York, Paris, and Amsterdam. ${ }^{38}$ In Bucharest, his work shown in an individual exhibition in April 1935 (again at Sala Mozart) was little understood. Brauner developed a friendship with the poet Gellu Naum, ${ }^{39}$ who was among the first to apply the techniques of automatism advocated by Breton in the Manifesto of Surrealism of 1924, and became one of the most important representatives of Romanian

37 In 1948, Brauner, in his refusal to sign the document expelling Roberto Matta from the surrealist movement, would himself be expelled. Both Matta and Brauner would be rehabilitated by Breton in 1959, at the time of the "Exposition internationale du surréalisme," Galerie Daniel Cordier in Paris (15 December 1959-26 February 1960). See “Dossier rupture surréaliste"(Victor Brauner, écrits et correspondances 279-283).

38 Specifically: "Exposition surréaliste," Tenerife, Galerie Ateneo de Santa Cruz, 11-21 May 1935; "International Surrealist Exhibition," London, New Burlington Galleries, 11 June-11 July 1936; "Fantastic Art, Dada, Surrealism," New York, Museum of Modern Art, 9 December 1936-17 January 1937; “Exposition internationale du surréalisme," Paris, Galerie des beaux-arts, 1938; "Exposition internationale du surréalisme," Amsterdam, Galerie Robert, Spring 1938.

39 Gellu Naum, after visiting the exhibition in 1935, is said to have remarked to Brauner, "Je voudrais écrire comme vous peignez" (Alexandrian, Victor Brauner 31) 'I would like to write the way you paint.' 
surrealism. ${ }^{40}$ Brauner illustrated Naum's first two collections of poems, Le Voyage incendiaire (1936) and Liberté de dormir sur un front (1937). When Naum arrived in Paris in 1938, Brauner introduced him to Breton's surrealist movement. And after the war, the first news that Brauner would receive from Romania came in letters from Gellu Naum, starting from 4 March $1945 .{ }^{41}$

The other great Romanian poet whom Brauner saw regularly during his final stay in Bucharest, and the other whom he would introduce to Breton in Paris in 1938, was Gherasim Luca. ${ }^{42}$ Brauner and Luca shared the same antifascist political struggle, publishing in the extreme leftist press and reviews (such as Lumea românească (The Romanian World)), with Brauner signing his drawings "Toto" or "V. Ber" (Victor Brauner, écrits et correspondances 214; Petreu 60-61). Brauner joined the Romanian Communist Party in 1936 and stopped painting. Instead, he drew caricatures or dreamlike evocations, such as the marvelous series titled "L'Anatomie du désir" ("The Anatomy of Desire") ${ }^{43}$ (1935-1936), which combined eroticism and derision. Writing plays a significant role in these drawings, affirming the necessity of the text-image connection in Brauner's work. In I937, outraged by the Moscow trials, Brauner distanced himself from communism and in secret began painting a series of paintings in small format, jarring witnesses to the desolation that reigned in Romania. ${ }^{44}$ In 1944, Brauner would return to these canvases, writing, "Mon inconscient, aurait-il à cette époque prévu où amène [sic-i.e. mène] dans ses images la guerre" 45 “My unconscious, had it foreseen in its images where this war is leading?' In Brauner's letters to Breton, the political tension in Romania was palpable: the painter evoked "le pays de la connerie" "the country of stupidity' and expressed his disgust toward the Romanian surrealist youth because of their "marxisme délirant-hystérie politique - ou - marxisme

40 Forced to return to Romania in late 1939, Naum and Luca created the Romanian surrealist group, and were joined by Paul Păun, Dolfi Trost, and Virgil Teodorescu (See Yaari).

41 Gellu Naum sent him news of his family, as well as of the friends they shared (Janco, Trost, Păun, Teodorescu); see the nine letters by Gellu Naum written in Romanian (4 March 1945-10 November 1965, eight of which date as late as 1948) in the Fonds Brauner, Paris, Bibliothèque Kandinsky, Mnam-Cci, Centre Pompidou inv. 8818-283 à 828. Thanks go to Doïna Lemny for her reading of them. Letters from Brauner to the poet are preserved at the Gellu Naum Foundation in Bucharest.

42 Luca and Brauner probably met in Bucharest early in 1931. Luca joined Brauner in Paris in 1938, where he remained for close to two years; at the Cité Falguière he was Brauner's neighbor.

43 See the series of eight drawings on paper (two dating from 1935 and six from 1936) preserved in Paris, Mnam-Cci, Centre Pompidou.

44 See note 52.

45 See manuscript (1944), in Victor Brauner, écrits et correspondances 34. Here, he alludes to La Ville qui rêve, and later on, to L'Envoyeur and Le Dernier Voyage, paintings dating from 1937 and held by Paris, Mnam-Cci, Centre Pompidou. 


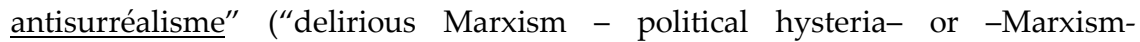
antisurrealism"). ${ }^{46}$ In another letter to Breton, Brauner praised the work of Saşa Pană, Sadismul adevărului (The Sadism of Truth), which developed the problematics of surrealism. ${ }^{47}$ In a letter the following year, Brauner characterized his stay in Romania as "exile": he spoke of Romanian political propaganda and witnessed "la mort d'une couche politique. LA mort de toutes les valeurs révolutionnaires pour la montée du fascisme lie des masses" "the death of a political layer. THE death of all revolutionary values in favor of the rise of fascism unites the masses.' Alluding to the surveillance to which he was subjected, he confessed to being "très fatigué à défendre cette démocratie" "very tired from defending this democracy.' He was impatient to leave for Paris again, but had no money. With the Romanian artists, "on travaille politiquement ensemble mais il y a le réalisme socialiste" 'we work together politically but there is socialist realism.' He signed his letter "Victor Brauner qui n'a pas trahi" 48 'Victor Brauner, who has not betrayed.'

Faced with the deteriorating political situation in Romania, which lurched from a parliamentary regime to a dictatorship committed to fascism and antiSemitism, and faced with an increasingly narrow and threatened artistic scene, Brauner felt isolated in his own country and chose to expatriate. In May 1938, he settled in France permanently. From his own country, Brauner maintained crucial friendships with several poets, a taste for craftsmanship and spiritism, magic and mystery, anticonformism and political rebellion through the presence of writing in his play with words and his signature. Later on, in 1949, following the acquisition of Progression pantactulaire ${ }^{49}$ (1948) by the Museum of Modern Art in New York, a questionnaire sent by Alfred Barr asked, "Votre nationalité, vos aïeux, votre expérience sont-ils pertinents à la connaissance de votre art ?" 'Are your nationality, your forebears, your experience relevant to understanding your art?' Brauner's response: "non" (after striking out "oui"), 50 indicated the complexity of the painter's relationship to his origins.

46 Brauner, Letter to Breton, Bucharest, [Winter 1935], Fonds André Breton BRT C 1727. Many thanks to Mme Aube Elléouët-Breton for allowing us to consult these letters and quote unpublished excerpts here.

47 Brauner to Breton, 4 December 1935 (Fonds André Breton BRT C 1728). Brauner is referring to their hope to create a photomontage of portraits of surrealists to illustrate the book that would be published in 1936 (Bucharest, Editura Unu) with the photomontage created by Brauner (reprod. in Semin, Victor Brauner 32) and illustrations by Brauner, Janco, Jarry, Kapralik, Perahim, Picasso, Man Ray, and Jacques Vaché.

48 Brauner to Breton, Bucharest, 17 September 1936 (Fonds André Breton BRT C 1730).

49 Progression pantaculaire, 1948, wax on cardboard, 50.2 x $69.8 \mathrm{~cm}$, New York, The Museum of Modern Art, gift of Dominique et Jean de Ménil, 1949.

50 Qtd. In Victor Brauner, écrits et correspondances 367. 


\section{"From the other side of the black borders" 51 : Dada and Surrealist Inventions (1938-1948)}

Brauner's work, begun in Romania, developed both outside and at the heart of Breton's surrealism, guaranteeing the painter his independence and complexity. He wrote: "Deux évènements capitaux: Mon accident à l'œil et la guerre" (manuscript (1944), in Victor Brauner, écrits et correspondances 39) 'Two capital events: The injury to my eye and the war.'

Leaving Romania permanently, Brauner took with him drawings and small format paintings ${ }^{52}$ which would enable his early works to be known. Upon arrival in Paris, he reestablished contact with the surrealists, especially Yves Tanguy and René Char. André Breton, still in Mexico City with Leon Trotsky and Diego Rivera, received these words from the painter:

Me voilà enfin ici, où j'ai tant désiré être. Je vous assure que pour moi, ça me paraît magnifique de vivre en France, surtout en ce moment, où vraiment en Europe il n'y a pas un seul endroit habitable. J'ai eu énormément de difficultés de tout ordre là-bas, des choses mºnt férocement retenu et paralysé dans cet ignoble pays. . . . En plus - la dictature du roi - dissolution de tous les partis politiques et arrestation du moindre suspect, je ne voulais pas être arrêté. Je reste maintenant ici où j'ai l'intention de m'installer pour très longtemps. ${ }^{53}$

Here I am finally, where I so desired to be. I assure you that for me, it seems magnificent to live in France, especially at this time when there is truly not a single livable place in Europe. I had difficulties of every order there, things that ferociously held me back and paralyzed me in that vile country. . . . In addition - the dictatorship of the king - dissolution of all political parties and arrest of the least suspect, I did not want to be arrested. I'm staying here now, where I intend to settle for a very long time.

To the 1938 edition of Lautréamont's works, prefaced by Breton and illustrated by several of the surrealists, Brauner contributed a portrait in which horns protrude

51 “De l'autre côté des 'frontières noires.'” Brauner, Letter to André Gomès, 4 April 1943, qtd. in Victor Brauner, écrits et correspondances 18 (note 25).

52 This series of paintings from 1937 is preserved at Paris, Mnam-Cci, Centre Pompidou (Trio, L'Envoyeur, La Mode, Sur le Motif, Le Dernier Voyage, La Ville qui rêve, Antithèse). It remains to be determined if Autoportrait (1931), a little larger, was left in Paris in 1935 or was also brought back from Romania in 1938.

53 Brauner to Breton, Paris, 12 July 1938, Fonds André Breton BRT C 2321.2 / 2. He considered these last years in Romania "d'une triste petite subjectivité" 'of sadly little subjectivity.' 
in place of the subject's eyes. This theme of the eye ${ }^{54}$ was an obsession with the painter. He himself became a "voyant" 'seer' and his painting became "magique" 'magic' when chance placed him in the middle of a scuffle between Oscar Dominguez and Esteban Frances (the night of 27-28 August 1938), and Brauner lost his left eye, the same one that he had represented as missing in his Autoportrait (of 1931). ${ }^{55}$ Didier Semin emphasizes that, thanks to this premonition, "Victor Brauner a été l'emblême [sic] de la mise en échec du rationalisme par les Surréalistes" (Semin, Victor Brauner 81) 'Victor Brauner embodied the failure of rationalism, as seen by the surrealists.' The story is widely present in Brauner's writings. In 1944, he would come back to this accident: with a view to publication he assembled several documents into a dossier that he titled "Le cas 'Victor Brauner'" 'The 'Victor Brauner' Case,'56 believing "cette brèche cyclopéenne" 57 'this cyclopean gap' forgotten. For the painter, this event was "un exemple presque unique dans l'histoire de l'art" 'an almost unique occurrence in the history of art.' Physician and writer Pierre Mabille, in an article published in the review Minotaure in 1939, stressed that the sacrifice of the eye "a non seulement delivré" "not only delivered' Brauner but also "[a] affirmé avec clarté et autorité ses idées" ‘affirmed his ideas with clarity and authority. ${ }^{58}$ And according to Didier Semin, the painter became "le point de rencontre par où les mythes ancestraux et la réalité se résolvent en peinture, en tableaux..." (Victor Brauner 89) 'the meeting point where ancestral myths and reality are resolved in painting and in paintings.' The Lycanthropes series (late 1938 to late 1939), populated by chimeras and werewolves, associated Freudian interpretation of dreams with the artist's visions (the somnambulist of Fălticeni reappears). Breton wrote in a letter to Brauner, "cela exprime au plus haut point le fantastique d'aujourd'hui " this is the highest expression of the fantastic of today.' ${ }^{59}$ The work possessed a symbolic function characteristic of surrealism and so much more magical in Brauner's work that he would begin alluding to alchemy by inserting the philosopher's stone in his fantastical compositions - thus imbuing them with the properties of

54 Introduced in 1925 in Sans Titre, Paris 1925 (preserved at Saint-Etienne, Musée d'Art moderne de Saint-Étienne-Métropole) in which the right eye of a decapitated head on a stake is pierced by a sort of spear.

55 See note 35 .

56 I am referring to the only collection compiled by the painter included in the Fonds Victor Brauner, published in Victor Brauner, écrits et correspondances 31-43 (ten of the photographs by Brauner were included in "Jeu photographique fait en Roumanie 1936" (Fonds Victor Brauner Ms 32 Inv. 8818.1100-11)). This project was not published during the artist's lifetime.

57 Draft letter to Dora Maar, 21 November 1944, in Victor Brauner, écrits et correspondances 38.

58 "L'CFil du peintre" 54. Mabille treated Brauner after his eye accident, and Jacques Hérold lodged him; they introduced him to Jacqueline Abraham in the summer of 1938. She would become Brauner's second wife after the war, in 1946. See Brauner, 2005, p. 190.

59 Breton to Brauner, 19 July 1939, Fonds Victor Brauner, Inv. 8818-60. 
metamorphosis and openings to the beyond. Initiation to alchemy and to the Kabbalah, probably beginning in 1938, offered Brauner the possibility of "tenter une approche globale de la réalité" (Semin, Victor Brauner 89) 'attempting an allencompassing approach to reality.' For him, it represented a tool that served to understand the world and its avatars, yet without becoming a hermetic vocabulary. Meeting the surrealist poet Robert Rius in the summer of 1938 was important for Brauner's initiation into alchemy. Rius, who appreciated the work of Ramon Lulle, a thirteenth-century Catalan philosopher, passed his knowledge and practice of esoterism on to Brauner (Victor Brauner, écrits et correspondances 244). In May 1940, Brauner illustrated Rius's first collection, Frappe de l'écho, with an etching centered on a "cristal" 'crystal' similar to the philosopher's stone that appeared in his work at the same time. ${ }^{60}$

In the winter of 1940-1941, the surrealists who gathered at the Villa Air-Bel in Marseille while awaiting visas to leave Europe ${ }^{61}$ created several collective works: exquisite corpses, as well as a deck of cards, loosely based on the Tarot of Marseille. Divination, which establishes a correspondence between popular images and a divinatory power, lay at the heart of the surrealist games from the beginning, with their intimations of clairvoyance and occultism. Combining chance with their taste for games and the symbolic characters drawn from a variety of sources (alchemy, literature, philosophy, the Revolution), André Breton and his friends designed a deck of fifty-two cards that rejected the military and religious references of the Tarot (Giraudy). Each participant drew the names of two personalities and figures to include. Thus Brauner drew Hegel and Helen Smith, the medium. The philosopher as "Génie de connaissance - Serrure" 'Spirit of Knowledge - Lock,' as the subtitle indicates, is endowed with a two-headed profile (a bearded man and the head of a leopard endowed with the tongue of a snake), recalling the "emblème du mythe et du double" 'emblem of the myth and the double' 62 in Brauner's work. The legend of Helen Smith, subtitled "Sirène de connaissance - Serrure" ("Siren of knowledge - Lock"), claimed that this medium was living again through real or imaginary characters, represented by Brauner as a somnambulist with two superposed heads with thick hair encompassing the full face and profile, and transforming it into a tiger with open jaw. For the surrealists, this game, beyond its links to Tarot and the Kabbalah, signified a free interpretation of the world,

60 La Pierre philosophale, oil on canvas, 1940, 65 x 81 cm, Saint-Etienne, Musée d'Art moderne de Saint-Étienne-Métropole.

61 These artists, anti-Nazi, Jewish, communist, foreign, etc., represented a "degenerate art," according to the German authorities. The American journalist Varian Fry, sent by the Emergency Rescue Committee (ERC - known in France as le Centre américain de secours) in August 1940, operated in Marseille during the war, enabling nearly three thousand people to flee Occupied France.

62 Brauner, Carnet havane à spirale (Nov. 1941-Dec. 1942), in Victor Brauner, écrits et correspondances 70 . The name Hegel is mentioned between those of Novalis and Breton. 
their imaginary world, and the isolation in which they found themselves; it also offered humor and derision, phantasms and hope. ${ }^{63}$

Sarane Alexandrian defined Brauner's painting as "une autobiographie, une dialectique, une mythologie, une thérapeutique et une ontologie " (Victor Brauner 55) 'an autobiography, a dialectic, a mythology, a therapeutic and an ontology.' In 1962, Brauner himself would write, “Ma peinture est autobiographique. J'y raconte ma vie. Ma vie est exemplaire parce qu'elle est universelle. . . . Elle raconte aussi les rêveries primitives dans leur forme et dans leur temps...." (Leymarie 84) 'My painting is autobiographical. In it I recount my life. My life is exemplary because it is universal. ... [My painting] also recounts primitive daydreams in their form and in their time. . . ' ${ }^{64}$ In another manuscript, he confides, "Toute mon œuvre est une simulation de mythologie. . . . Le Mythe du Surréaliste se dessine étant le Mythe de l'homme à venir " (Fonds Victor Brauner, inv. 8818-1106/1) ‘My work is a simulation of mythology. ... The Myth of the surrealist emerges as the Myth of man (mankind) to come.' Magic would continue to guide his creative work, especially in the darkest periods during the war when his status as Jew, Romanian, and former communist, in addition to his illegal status in France forced him into hiding. ${ }^{65}$

Brauner would then experiment with manipulating other materials and techniques. Despite the shortage of materials, in 1941 he invented "Dessin à la bougie" 'Candle drawings' 66 , which he theorized in July 1943 while in hiding at Celliers-de-Rousset. One of the most important wartime transformations in Brauner's art, this technique called for using wax as a material in paintings and works on paper. In his text, ${ }^{67}$ the painter related how observing the rocky shores of the Durance river had inspired the idea of using a candle. Associating the spectacle of nature with the creative process, Brauner drew a parallel between the

63 Of the surrealists who participated in the Card game of Marseille, Óscar Domínguez, Jacques Hérold, and Brauner would stay in France. In serious danger, Hérold and Brauner, Jewish and in France illegally, were unable to obtain visas, despite the efforts of Varian Fry and the Comité américain de secours à Marseille. With respect to this failure, we can posit these two factors: the fact that Brauner's name does not figure on the first list of the ERC and his nationality (Romania entered the war on the side of Nazi Germany in June 1941). These factors also applied to Hérold's situation.

64 V. Brauner, Fonds Victor Brauner, published in Leymarie 84.

65 For a chronology of this period, see Victor Brauner, écrits et correspondances 372-84.

66 This text went through several drafts (see Victor Brauner, écrits et correspondances 82 and 117) and was published in Cahiers d'art in the 1945-1946 issue (during the painter's individual exhibition, Paris, Galerie Pierre, 20 March-7 April 1946), then in English translation in the exhibition catalogue Victor Brauner by Julien Levy in New York in April 1947 (see Victor Brauner, écrits et correspondances 400-01).

67 Recopied and penned with care in the Cahier "L" (1943-44), reprod. in Victor Brauner, écrits et correspondances 399 . 
two. The technique took on philosophical and universal dimensions. The artist applied different layers of wax, covered in ink, which he then scraped with a pointed object, giving way to drawings and writing. Through this invention Brauner materialized the dialectic and conciliation of opposites in a "noce chimique" 'chemical marriage,' an expression alluding to esoteric writing and to the work of Christian Rosenkreutz, excerpts of which Brauner had read in Le Miroir du merveilleux, an anthology of poetic and esoteric texts edited by Pierre Mabille. ${ }^{68}$ The candle paintings developed the link between text and image, adding a new perspective: the wax imbued the work with mysterious powers of revelation, echoing Brauner's formula in his theoretical text, that is, the Alpha and the Omega, associating opposites "selon les lois des correspondances secrétes [sic]" (Victor Brauner, écrits et correspondances 399) 'according to the laws of secret correspondences.' A relationship to the work of Paul Klee ${ }^{69}$ can be discerned in these inventions, and Brauner's quest for new processes recalled the surrealist techniques developed in the 1930s and 1940s through their emphasis on the element of chance, especially those of Max Ernst, for whom the support became a source of revelation, like scraping and decalcomania, for example.

Some of Brauner's wax paintings also include collages, perhaps in memory of the assemblages developed in the Dada or surrealist reviews. Analogies, reminiscences, or reprises can be imagined: for example, the Fiancée mécanique $(1945)^{70}$ metamorphoses into a machine, recalling Francis Picabia (see Voilà la Fille née sans mère, [1916-1917] $)^{71}$ in which the sexual mechanism is reduced to a pure object. In Homme idéal (1943), ${ }^{72}$ Brauner sectioned a human body into five parts from the head to the genitals, each comprised of a drawing and of words defining the corresponding morphology. In the motifs represented (stomach and heart) we find the mechanomorphic forms of Picabia who had hoped to imperil painting with his iconoclastic compositions in the 1910s. The various styles and the layering of the drawings may also allude to the surrealist exquisite corpse compositions. The invention of "candle drawings" stems from an important shift in Brauner's painting that suggests a transfer of energy from materials (with magical virtues)

68 A copy is preserved in Brauner's library, L 199. Brauner would use C. Rosenkreutz's Noces chimiques for inspiration in the writing of Promenade. See note 114.

69 Emphasized by Brauner in a letter to Breton, [Paris], 10 December 1945 (Fonds André Breton BRT C 245).

70 Wax, dye, walnut shell and ink on cardboard, 63.5 x $48 \mathrm{~cm}$, Houston, The Menil Collection.

71 Watercolor, gouache - silver, black ink, pencil on cardboard, 75 x $50 \mathrm{~cm}$, Paris, Mnam-Cci, Centre Pompidou. Picabia's drawings for the review 391 (1917-1924) also served as sources of inspiration.

72 Wax and pen on paper glued to wooden panel, 37 x $16.5 \mathrm{~cm}$, Paris, Mnam-Cci, Centre Pompidou. 
to representation (incised text and images), resulting in the production of works reminiscent of ex-votos and talismans, thus protecting the painter. ${ }^{73}$

This profound transformation, long prepared by the artist since his eye injury, was not due only to the conditions in which Brauner was living. Above all, it corresponded to the painter's vision since his early years, since joining surrealism, since discovering primitive art (cave painting, African and Oceanic art, Egyptian painting), since beginning to explore alchemy and the Kabbalah, ${ }^{74}$ etc., bringing him back to "le jeu extravagant de l'archaïsme permanent ... qui existe en substrat, à la base" 'the extravagant play of permanent archaism . . . which exists in the substrata, at the base.' 75 Finally, Brauner persisted in approaching "une essence primitive de l'art, qui est de se moquer de la technique" a primitive essence of art, which is to flout technique,' in the spirit of Claude Levi-Strauss's notion of "bricolage," in which "l'art se donne pour but la transformation immédiate du monde, en forçant des éléments imparfaitement joints à tenir ensemble" 'the goal of art is the immediate transformation of the world, by forcing imperfectly joined elements to hold together,' to quote Didier Semin (Victor Brauner 117-19).

At the same time in and in the same vein, Brauner executed objects containing kabalistic signs and numerological correspondences, especially relating to Saturn. As Fabrice Flahutez notes, "Victor Brauner applique les conclusions freudiennes dans la construction d'objets ayant des propensions à conjurer le monde" ("Figurer l'inconscient"266) 'Victor Brauner applies Freudian conclusions by constructing objects that have a propensity for conjuring this world.' In Freud's line of thinking in Totem and Taboo, Brauner's object becomes the vehicle of beneficial and/or evil powers. In a notebook dated 1943-1945, Brauner copied passages from Amulettes, talismans et pantacles dans les traditions orientales et occidentales, by Jean Marquès-Rivière. ${ }^{76}$ This anthology included the Treatise of Cornelius Agrippa von Nettesheim, which described magic squares and pentacular seals, like the seal of Saturn, who became a protective god (dieu

73 Ten wax paintings are described by the painter in short notes written in a notebook between 1943 and 1946; see Victor Brauner, écrits et correspondances 85-89.

74 Semin stresses that it "est difficile de départir si [les éléments de la tradition juive] remontent à l'enfance de Brauner ou s'ils sont empruntés aux ouvrages kabbalistiques qu'il consultait" (Semin, "Talismans") 'is difficult to determine whether [the elements of Jewish tradition] go back to his childhood or whether they are borrowed from the Kabbalistic works which he consulted' in Brauner, Lausanne, 1999, p. 42.

75 Brauner, interview with Alain Jouffroy, "Victor Brauner peint un tableau devant vous," in Connaissance des Arts 107 (Jan. 1961), qtd. in Semin, Victor Brauner 117.

76 This book, which Brauner unquestionably possessed at that time, is no longer in his collection, probably due to the fact that the author participated in the anti-Semitic policies of the Vichy government by publishing pamphlets and through his collaboration in the exhibition "Le Juif et la France," in Paris at the Palais Berlitz, 5 September 1941-15 January 1942. 
protecteur) for Brauner. The seal of Saturn and other associated signs appeared in two works from 1943, Les Amoureux and Objet de contre-envoûtement (Object of counter-spells). ${ }^{77}$ Assembling in a wooden box elements that surrounded him, Brauner created objects endowed with magic power to protect him from the perils looming for him in Occupied France. He integrated sculpture and drawing into his writing, which wove together "avec beaucoup de liberté et même d'humour" (Semin, "Talismans") 'with much freedom and even humor' ideograms of the Kabbalah, Hebrew letters, and cryptic characters of an Adamic idiom that can be deciphered using the Treatise of Agrippa von Nettesheim and the anthology of Marquès-Rivière (Kuni 14-16). These assemblages, created in the tradition of popular practices, and invoking Saturn, became vital, magic talismans that Brauner would keep in his studio all his life. Two other assemblages used the same principle and the same references to the Kabbalah, also paying homage to Novalis, ${ }^{78}$ a decisive figure for Brauner, who in November 1941 confided in a notebook his growing immersion in the German romantics, such as Novalis, Jean Paul, and Goethe. These counter-spell objects "se rattachent à cette double fonction du totem et du tabou: ils cristallisent l'interdit et la pulsion dans la mesure où leur fascination demande le toucher, tandis que l'aspect repoussant sert d'exutoire" (Flahutez, "Figurer" 266) 'are bound to this double function of totem and taboo: they crystallize the forbidden and the sex drive in that the fascination that they exert elicits touching, while the repulsive aspect serves as a release.'

Responding to the quest for a new myth, central to the surrealists in the 1930s to 1940 s, Brauner continued his research, creating sculptures executed during this same period. His three-dimensional works related to the most secret doctrines laid out, such as Nombre (1943-1945), ${ }^{79}$ which associated primitive influences like Egyptian statuary, or Double vivification (1943), ${ }^{80}$ which used "la représentation alchimique de la transformation de la pierre philosophale" 'the alchemical representation of the philosopher's stone's transformation,' a way for Brauner "de mêler poétiquement plusieurs champs distincts: l'alchimie et la Kabbale, l'occultisme et le mythe du Golem" (Flahutez, "La bibliothèque de Victor Brauner" 189) 'to mix poetically several separate fields: alchemy with the Kabbalah, and occultism with the myth of the Golem.'

\footnotetext{
77 Preserved at the Mnam-Cci, Centre Pompidou.

78 See Portrait de Novalis et Image de l'irréel incréé, objects dating from 1943, Paris, Mnam-Cci, Centre Pompidou.

79 Plaster, lead, porcelain, 164 x 64 x 64 cm, Marseille, Musée Cantini. See Morando, "Brauner, Nombre."

80 Polychrome plaster, 31.7 x 13.8 x 7.4 cm, Paris, Mnam-Cci, Centre Pompidou.
} 
Brauner's correspondence addressed to his friends revealed this new direction in his creative activity and his eagerness to share his inventions. ${ }^{81}$ In a letter to Breton in 1945, he summarized all his current work in the words "matérialisme diabolique" 82 'diabolical materialism' and confided his desire to pursue "le surréalisme comme la seule méthode possible dans les orientations nouvelles de l'homme à la recherche d'une mythologie qui le délivrera du spectre de la plus effroyable angoisse, celle de la solitude dans la vie moderne" 83 'surrealism as the only possible method in man's new directions in search of a mythology which will deliver him from the specter of the most terrifying anguish, that of solitude in modern life.' His candle paintings, his counter-spell objects, and his sculptures all question the status of the work of art, or of the image itself. As a tool of resistance, these plastic works, that borrow partially from Dada assemblages and surrealist compositions, become "agissantes" 'active' and possess magical properties, like talismans.

\section{"The Uncreated Unreal" 84: The Invention of a Writing}

As Alain Jouffroy writes, Brauner's work “unifie réel, surréel, irréel, préréel et post-réel en un monde complet, que l'on pourrait appeler la panréalité" (42) 'unifies real, surreal, unreal, pre-real and post-real in a complete world, which we might call "panreality,"' bestowing on the "phénomène mental . . . une réalité plus forte que celles des objets" "mental phenomenon . . . a reality stronger than that of objects.' It is accompanied by numerous writings, recorded in different notebooks and manuscripts. The abundance of pages (close to 7,700), the "journal" he kept regularly, his attachment to language, his literary inventions, his recopying of certain texts, and his desire to be published all attest to the importance of writing for Brauner. Furthermore, as mentioned earlier, writing is latent in his plastic work, blurring the line between the different supports (paper, canvas, cardboard). Since inventing pictopoetry in Romania, he played with words, their hidden meaning or typography, their appearance or disappearance, in character with the ludic and clandestine avant-garde of his early days, which Brauner would continue to pursue to the end of his life. In this same vein, the evolution of the

81 He would share them with René Char, also with Henriette and André Gomès beginning in August 1943 (Victor Brauner, écrits et correspondances 398) and with André Breton (see the letters that Brauner wrote to him beginning in June 1945, Fonds André Breton BRT C 242$45)$.

82 Brauner to Breton, Paris, 16 October 1945 (Fonds André Breton BRT C 244). This expression turns up again in "Proclamation," published in the exhibition catalogue $L e$ Surréalisme en 1947 (reprod. in Victor Brauner, écrits et correspondances 403).

83 Brauner to Breton, Paris, 27 September 1945 (Fonds André Breton BRT C 243).

84 “L'irréel incréé,"Brauner's expression inspired by "l'inextinguible réel incréé" in René Char's poem "Partage formel." See Victor Brauner, écrits et correspondances 170. 
painter's signature questioned the notion of identification through his tendency to

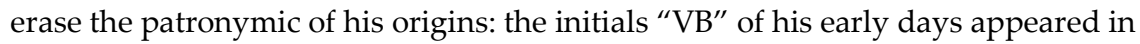
printers letters, then starting in 1929, the angle of the " $\mathrm{N}$ " of Brauner was reversed; 85 from 1943, the font was enriched by means of "pelleted" (bouletées) letters, a technique borrowed from Hebrew amulets (Victor Brauner, écrits et correspondances 91); and beginning in 1948, reference to his last name disappeared to be replaced by the sign for infinity " $\infty$ " in order to "témoigner de son enracinement panthéiste dans le monde" (Semin, Victor Brauner 89) 'signify his pantheistic rootedness in the world, while preserving his first name, which means "victorious" according to Latin and Romanian etymology, or by keeping only the initial "V." Sometimes the artist's signature figured beside the title. ${ }^{86}$ Absent from compositions in the beginning, the title started to appear, around $1943^{87}$ and then with increasing frequency, in a box at the bottom or top, like a title block. Brauner's attention to the titles of his works speaks of his taste for writing and words, which grew out of his prolific reading that would always be an indispensible resource for him. His penchant for the German Romantics led him, despite Nazi barbarity and despite being in hiding, to title one of his anti-spell objects, "Bildnis aus der ungeschöpften Wirklichkeit" (which he translated as "Image du réel incréé" 'Image of the uncreated real'). ${ }^{88}$ This is a sign of the painter's attachment to this literary movement.

Brauner's native language occasionally reappeared in his titles and "des mots à consonance bizarre, des mots roumains viennent s'ajouter à l'effet cryptique de certaines toiles" "strange-sounding words, Romanian words add to the cryptic effect of certain canvases': "Leur traduction amplifie l'impact poétique des images ou, dans certains cas, nous révèle des sens inattendus (Origine de la Vorba (1946) = Origine de la parole ; Inima la Convulsionnaire (1946) = Le cœur convulsionnaire ; Tot in Tot (1942) = Le tout dans le tout, etc.)" 'Their translation amplifies the poetic impact of the images or, in certain cases, reveals to us unexpected meanings (Origine de la Vorba (1946) = Origin of the Word; Inima la Convulsionnaire (1946) = The Convulsing Heart; Tot in Tot (1942) = All in All, etc.)" 89

In the same way that writing intervened in Brauner's visual works, drawing is present in his texts, not only to illustrate his ideas, but also to add a playful or

85 A characteristic that he would continue all his life, after his last name began reappearing in the early 1950 s.

86 Even to the point of mixing in with it, as in 1949 in the series of paintings titled "Victor Victorel."

87 With a few exceptions, including Légèrement chaude ou Adrianopole, 1937, oil on wood, 13 x $17 \mathrm{~cm}$, former collection André Breton, reprod. In Semin, Victor Brauner 89.

88 See note 84 . This object is dated 1943, wax assemblage, flint, and string in a box protected by glass, 28.8 x 18.6 x 6.5 cm, Paris, Mnam-Cci, Centre Pompidou.

89 Vanci-Perahim, "Le Lisible et le visible" 68. Note that in fact Brauner had titled the painting "ORIGINE DE VORBA" and that Tot in tot was created in 1945. 
poetic element (an animal drawn in place of a cross-out) ${ }^{90}$ or a cynical element (heads of Hitler and Hindenburg, ${ }^{91}$ a swastika ${ }^{92}$ ). In all cases, his drawing was inventive and his language no less so.

The writings of Victor Brauner that survive are almost all written in French. ${ }^{93}$ As is evident from the dates of the archive contents (1929-1984), his Romanian years are very little represented. His native language seems to have disappeared early in the 1930s in favor of French, a clear sign of his break with his country. We don't know when Brauner learned French, but awkward vocabulary and syntax lead us to believe that he started writing in French during his first stay in Paris in 1925, as implied by the titles of some of his drawings. ${ }^{94}$

The only surviving notebook written entirely in Romanian ${ }^{95}$ probably dates from 1939, judging by a drawing (a fragment torn from the same notebook at some point) that is dated 31 May 1939. ${ }^{96}$ As Sylvie Patry has noted, Brauner "se pose la question de la transposition plastique immédiate de l'image rêvée, et dresse une nomenclature optique et psychologique des images selon leur nature, en distinguant une composante première, la 'virgule intro-plastique,' sorte de microparticule" (Patry, "Cahier vert") 'wonders about the immediate plastic transposition of the dreamed image, and creates an optic and psychological nomenclature of images according to their nature, distinguishing in them a primary element, the "intro-plastic comma," a sort of microparticle.' The choice to use Romanian can no doubt be explained by Brauner's difficulty outlining his most abstract theories in French at that time. The painter sketched a study of the eye's perception and of his introspective and retrospective process, arguing in favor of "une restitution mouvante et floue des formes plastiques" 'a moving and hazy restitution of visual forms. ${ }^{97}$ More typically, his correspondence, especially with his family and with Gellu Naum, took place in Romanian. ${ }^{98}$

\footnotetext{
90 See Victor Brauner, écrits et correspondances 53 (fig. 13).

91 With no connection to the text; Victor Brauner, écrits et correspondances 58.

92 Relating to the words, "Objet pour se faire une place dans le métro" ‘Object for creating some space for oneself in the metro,' reprod. in Victor Brauner, écrits et correspondances 26 (fig. 12).

93 See my "Profession: Picto-poëte," portions of which reappear in the present essay.

94 On the watercolor dedicated to the city, Brauner writes "Paris est grand" (in Stella 45, without reference to the aforementioned drawing).

95 Published in French in Victor Brauner, écrits et correspondances 44-45; see also 22 (note 4).

96 Reprod. in Victor Brauner, écrits et correspondances 107 (Pl. 2).

97 Patry, "Cahier vert". The images described refer to the Lycanthropes series, in particular.

98 Also his exchanges with the painter engraver Dimitri Varbanesco, in Victor Brauner, écrits et correspondances 277-78. Note that the majority of the letters from Gherasim Luca (with three exceptions) between 1946 and 1948 were written in French. See Victor Brauner, écrits et correspondances $214 \mathrm{ff}$.
} 
During his second stay in Paris (1930-1935) Brauner chose to adopt French again, and the language of exile became the object of invention, upon which Romanian would leave an imprint, sometimes as an obstacle, sometimes as enrichment. Syntax seemed to suffer most. His vocabulary was very rich in descriptive metaphors and in dreamlike, magic, and pictorial adjectives. A few invented words ("difformation," "supprimation") assured his eye accident a place "sans pareil dans l'histoire de l'art" 'without equal in the history of art.' 99 Other neologisms, simple spelling errors in the beginning, became veritable Braunerisms: "hazard," "érosïme," "indésirabilité," etc., and the total absence of accent marks in some expressions highlights the importance and whimsical character of "poësie" and "poëte," in particular. Brauner also used René Char's poetic expressions to translate his obsessions during the war, making these expressions his own in his texts "Sabre bubonique" ‘Bubonic Saber' and "Homme à tête d'accident" 'Man with an accident head' (Victor Brauner, écrits et correspondances $26,168,382,404)$. Brauner also manipulated metaphors, especially to avoid naming the Nazis, whom he described as "les ouvreurs de braguette" 'openers of flies,' 100 an expression allowing Brauner to evoke his Jewishness discretely.

Faulty verb conjugation contributes to the unclear timeframes and to a reflection on time that runs throughout the writings of a painter who scrupulously noted the day and time of his writings and visual creations. Out of these difficulties and encouraged by his friends, such as René Char ("écris tes projets, tes idées" 'write your plans, your ideas,' 101 Brauner invented a language, as much through style as in the subjects addressed, and exalted by a will to say all, he reached toward a universalism of creation, eternally identical yet differently described.

Brauner's isolation during the war accentuated his need to write, "la vie nomade [étant] défavorable à la peinture" 'the nomadic life [being] unfavorable to painting.' 102 Yet, most often, he wrote much because he painted and created much. His texts, highly prolific during the war and essentially dedicated to documenting and explaining his creative process, lent insight to his indefatigable turn to writing, either to share with his friends or to record his research. His writing thus added to his visual creation, rather than supplanting it. As he confided in 1948,

99 Brauner, Manuscript (end of 1944), in Victor Brauner, écrits et correspondances 37.

100 Also "déculotteurs de braguette" 'pants pullers,' in Victor Brauner, écrits et correspondances 26.

101 Letter from René Char to Brauner, 14 December 1942 (Victor Brauner, écrits et correspondances 168).

102 Brauner, letter to René Char, Saint-Féliu d'Amont, 17 July 1941 (Fonds René Char, CH 476), qtd. In Victor Brauner, écrits et correspondances 18. Many thanks to Mme. Marie-Claude Char for allowing us to quote these excerpts once again. 
Ceci vient d'un profond désir d'écrire mes impressions, où dans la part disponible (ah ! qu'elle est grande et exigeante) de ma disponibilité complète à [sic] l'impression. N'est-on pas en permanence à la pêche miraculeuse? Plongeur à main sûre en soi-même scaphandrier de ses sensations sélectionnées, le poëte tout homme, sur-héros cherche la stimulation de l'imagination, le jet d'eau en flamme impulsive de la création. ${ }^{103}$

This comes from a deep desire to write down my impressions, which in the available part (oh! so great and demanding) of my availability completes the impression. Are we not always plumbing the depths for the miraculous? Sure-handed diver into himself as an undersea diver of selected sensations, the poet, all man, superhero, seeks the stimulation of the imagination, the impulsive flaming water jet of creation.

Thus constituted, the painter's style is often lyrical, rhythmed by repetitions and digressions, depending on the subject ${ }^{104}$ (painting, love, despair, war, isolation, friendship, absence, poetry, dreams), engaging with the invention of writing. Brauner explored different genres: journal, poetry, essay, explanatory notes, correspondence, and fiction. The line between genres is sometimes blurred: pages of his journal include letter drafts, short poems, essays, and fragments of fiction; and inversely, a letter sometimes becomes a place to recopy a poem, theoretical text, excerpt from a book, etc. Poetry, present from the early 1920s and shared with his poet friends (Char, Gherasim Luca, Naum, Voronca, Paul Păun, Breton, Hubert Juin), was renewed with the writing of poems in prose. ${ }^{105} \mathrm{His}$ theoretical writings discuss the results of his artistic research and inventions, which he often included in autobiographical stories ("Congloméros," "Du fantastique I en peinture II en théâtre" (On the fantastic I in painting II in the theater), "Dessin à la bougie," "Proclamation"), some of which were published (Victor Brauner, écrits et correspondances 394-404). Numerous literary notes describe plays in minute detail or outline projects for paintings or sculptures. ${ }^{106}$ In the same way, he lays out plans for a ballet and for exhibitions, ${ }^{107}$ as well as plans for a "poem-film" on love to be "traité comme en rêve" 'treated as a dream.' 108

${ }^{103}$ V. Brauner, “Cette plume n'a plus quitté mon chapeau . . .," 2 January 1948, reprod. In Victor Brauner, écrits et correspondances fig. 7 p. 19.

${ }^{104}$ Especially for the dates 1938-1948, the latest period in which he revisited these subjects, adding writing on the painters, contemporary art, etc.

105 See especially those in the "Carnet bleu à spirale" (1941-1945) (Victor Brauner, écrits et correspondances 63-64).

106 See, for example "Petit carnet long noir" (Victor Brauner, écrits et correspondances 83-89).

107 See Manuscrit (Victor Brauner, écrits et correspondances 100-105).

108 See letter from Brauner to Sylvain Itkine, Marseille, 9 March 1942 (Victor Brauner, écrits et correspondances 204-205). 
To this writing "pour soi" ("for oneself") must be added his correspondence, sent, recopied, or imagined in a free and lyrical style, correspondence in which Brauner keeps revisiting the same expressions, the same words on the subjects raised. His letter drafts are like a journal in which he is motivated by the need to interact with those who are absent. ${ }^{109}$ The subject most present in Brauner's writing is his own creation, which runs into the vagaries (richness and resistance) of writing. This can be seen in the painter's sole work of fiction: Promenade, sketched out as early as May 1941 and written between June 28 and late October 1941 , no doubt with an eye to publication. ${ }^{110}$ It is the only example of his fiction that has survived. ${ }^{111}$ This narrative, developed over time by Brauner through numerous drafts and clean copies, was reconstructed and edited in its entirety for the first time in 2005 for inclusion in Victor Brauner, écrits et correspondances, 19381948. ${ }^{112}$ Promenade describes the nocturnal wanderings of a painter accompanied by twenty-five "beneficial" objects, which seem both to deliver a treasure and hold a secret. The long sentences lead the reader into a fantastic and chaotic universe invented by the author. The story opens with these words:

Cette nuit encore, je me suis réveillé à mon heure habituelle et je suis sorti aux bruits multiples du silence nocturne et mes amis de nuit et déjà les crapauds m'attendaient et approchaient et m'accompagnaient à la recherche de ce chemin que j'avais, enfin, trouvé à la fin de la nuit dernière, après des années de recherches minutieuses.

Again that night, I awoke at my usual hour and I went out to the many noises of nocturnal silence and my friends of the night and already the toads were waiting for me and approached and accompanied me on my search for the path that I had finally found at the end of the preceding night, after years of minute research.

In the course of the story, the quotidian surfaces ("les armées d'envoûteurs" "the armies of bewitchers,' the handwriting changes to avoid being identified), and the obsessions of the painter immerse the reader: danger, penury, love with the

109 On 25 March 1964, Brauner wrote "Lettre à personne" 'Letter to No one,' refusing to fill the void with the story of his memories (Fonds Victor Brauner, Inv. 8818-1097/23, excerpts published in Bozo 13 and in Victor Brauner, écrits et correspondances 24).

110 This project, proposed to Dina Vierny and Peggy Guggenheim, would be abandoned, and several drafts and fragments would not be included in the journals of recopied texts.

${ }^{111} \mathrm{He}$ would sketch out two other short works of fiction; see Victor Brauner, écrits et correspondances 23 (note 23).

112 See my reconstruction in Victor Brauner, écrits et correspondances 50-61; see also 49 (notes 1 and 3). Excerpts without reference to the title "Promenade" were published in Semin, ed., Victor Brauner dans les collections du MNAM-CCI 102-112. 
romantic presence of "L" (Laurette Séjourné113), Kabbalistic symbols, and enucleation. On this magical night, the narrator (named "Vittorio") meets his double, a one-eyed painter. Brauner plays on the idea of mise en abyme by presenting a dreamlike autobiographical text. The painter, along with his collection of twenty-five objects that are both his treasures and a testimony of the misery in which Brauner was living (a small piece of wood, a shoelace), is propelled into a world marked by constant metamorphosis and peopled by sleepwalkers. Beyond the actual story, Brauner attempts to perform a synthesis of his endogenous connections with the Romanian avant-garde, surrealism, alchemy, and his solitude. The artist was broadly inspired by "Chemical Marriages" by Christian Rosenkreutz (but attributed to Valentin Adreae, who claimed to have written it around 1610), which he encountered in Mabille's Le Miroir du merveilleux, described as "le singulier voyage d'un initié" 'the singular voyage of the initiated'114: the visit to the chateau, the presence of the egg, the secret of the "chemical marriage," and the various stages of the narrator's journey appear in many places in Brauner's Promenade. The story ends with a text titled "Térapeutique ${ }^{115}$ de démoralisation ou contre inspiration" (Terapeutic of Discouragement or Counter-Inspiration); after dreamlike visions and reflections on painting, the painter-narrator tries to reach "Al-nec-Nadou,"116 the "pays lointain de [ses] ancêtres" 'faraway land of [his] ancestors' where all is possible. Brauner's plan to publish the book was not realized in his lifetime. Still, this long text demonstrates real literary invention, describing struggles and phantasms, with a rich visual dimension that reinforces the correspondence between text and image.

Victor Brauner continued to write tirelessly until the end of his life, pursuing his games of invention in his writings, more measured and lucid but always dedicated to creation, his discoveries and his questions concerning art and its reception, and always motivated by a desire to exchange and to be read. His need to write points to a need to have some form of work in process. And, ranging from writing to the plastic work, the painter developed a new magical language, a ritornelle of words and images. Having participated in the Romanian avant-garde from the beginning, and developing an original surrealist body of work nourished by erudite fields of study (alchemy, the Kabbalah, tarot, the German Romantics), Victor Brauner sought to recapture a lost unity, and in so doing, constructed an intense and personal cosmogony. Brauner's writing and his plastic creation, intimately connected, complete, nourish, and constantly use the marvelous

113 With whom Brauner was hopelessly in love in Marseille from 1941-1942 (Victor Brauner, écrits et correspondances 250-251ff).

${ }^{114}$ Le Miroir du merveilleux 94 . See note 68.

115 Incorrect spelling by Brauner, perhaps an allusion to terato (monster, in Greek) (Victor Brauner, écrits et correspondances 61).

116 No doubt an imaginary place. 
inventions of the man who wrote, "chaque dessin, chaque découverte sera un extraordinaire lieu inconnu, chaque tableau sera une aventure" 'each drawing, each discovery will be an extraordinary unknown place, each painting will be an adventure.' ${ }^{117}$

Translated from the French by Lynn Palermo.

\section{Works Cited}

Alexandrian, Sarane. Victor Brauner. Paris: Oxus, 2004. Print. Les Étrangers de Paris: Les Roumains de Paris.

—. "Victor Brauner." L'CEil, 101 (May 1963): 32-39, 68. Print.

“Bitte zu lesen." 75 HP (Oct. 1924): p. 4 of cover. Print.

Binoche et Giquello. Collection d'un historien d'art européen: Quatrième Partie et à divers, important ensemble concernant Victor Brauner, avant-gardes du XXe siècle, éditions originales, livres illustrés, revues, manuscrits, lettres autographes, photographies, dessins, tableaux. Paris: Binoche et Giquello, 2013. Print.

Brauner, Victor. "Dessin à la bougie." Cahiers d'art 20-21 (1945-46): 314.

. "My Drawings in Wax." Trans. J.B. Victor Brauner. New York: Julien Levy Gallery, 1947. N. pag. Print.

. “Proclamation.” Le Surréalisme en 1947. Paris: Pierre à Feu, Maeght, 1947. 25-26. Print.

- Victor Brauner, écrits et correspondances, 1938-1948: Les Archives de Victor Brauner au Musée national d'art moderne. Ed. Camille Morando and Sylvie Patry. Paris: INHA/Centre Pompidou, 2005. Print. Archives de la Bibliothèque Kandinsky.

Brauner, Victor, and Ilarie Voronca. "La Pictopoésie." 75 HP (Oct. 1924): p. 4 of cover.

Breton, André. “Botte Rose blanche.” Victor Brauner. Paris: Galerie Pierre, 1934. N. pag. Print.

Char, René. "Partage formel." Seuls demeurent. Paris: Gallimard, 1945. 69-85. Print.

Fauchereau, Serge. "L'Itinéraire de Victor Brauner." Victor Brauner, ou, L'enchantement surréaliste. Lausanne: Fondation de L'Hermitage, 1999. 10-23. Print.

\footnotetext{
117 Brauner, Manuscript, (November 1941-December 1942], qtd. in Victor Brauner, écrits et correspondances 22 .
} 
Flahutez, Fabrice. "La bibliothèque de Victor Brauner et la bibliothèque d'André Breton: Surprises et limites du comparatisme." Les bibliothèques d'artistes: XXe-XXIe siècles. Ed. Françoise Levaillant, Dario Gamboni, and Jean-Roch Bouiller. Paris: Presses de l'Université Paris-Sorbonne, 2010. 107-27. Print.

_. "Figurer l'Inconscient dans le dur: Les Totems de Victor Brauner et d'Anton Prinner." Hypnos: Images et inconscients en Europe (1900-1949). Lille: Musée d'art moderne Lille métropole, 2009. 264-75. Print.

Fonds André Breton. Paris, Bibliothèque littéraire Jacques Doucet. Mss.

Fonds René Char. Paris, Bibliothèque littéraire Jacques Doucet. Mss.

Fonds Victor Brauner, Paris, Mnam-Cci, Bibliothèque Kandinsky. Mss.

Giraudy, Danièle, ed. Le jeu de Marseille: Autour d'André Breton et des surréalistes à Marseille en 1940-1941. Marseille: Musées de Marseille, 2003. Print.

Jouffroy, Alain. Victor Brauner. Paris: Fall, 1996. Print.

Kuni, Verena. "Objets." Victor Brauner dans les collections du MNAM-CCI. Ed. Didier Semin. Paris: Centre Pompidou, 1996. 12-17. Print.

Lautréamont, comte de. CEuvres complètes. Introd. André Breton. Ill. Victor Brauner et al. Paris: GLM, 1938. Print.

Lemny, Doïna. "Projet pour une affiche de théâtre." Victor Brauner dans les collections du MNAM-CCI. Ed. Didier Semin. Paris: Centre Pompidou, 1996. 50. Print.

Leymarie, Jean. Victor Brauner. Paris: Réunion des musées nationaux: 1972. Print. Mabille, Pierre. Le Miroir du merveilleux. Paris: Sagittaire, 1940. Print. . "L'CEil du peintre."Minotaure 12-13 (May 1939): 53-56. Print.

Marquès-Rivière, Jean. Amulettes, talismans et pantacles dans les traditions orientales et occidentales. Paris: Payot, 1938. Print.

Montagne, Margaret. “Biographie." Victor Brauner, ou, L'enchantement surréaliste. Lausanne: Fondation de L'Hermitage, 1999. 113-20. Print.

Morando, Camille. "Brauner, Nombre." Traces du sacré. Paris: Centre Pompidou, 2008. 214. Print.

—. "Le Portrait de Benjamin Fondane par Victor Brauner (1931)." Cahiers Benjamin Fondane 13 (March 2010): 12-17. Print.

—. "'Profession: Picto-poëte': L'Écriture de Victor Brauner." Victor Brauner, écrits et correspondances 21-26. Print.

- "'Térapeutique [sic] de démoralisation ou contre inspiration' chez Victor Brauner: L'Invention d'une écriture dictée par la privation et l'absence." Arts drogués: Expériences psychotropiques et création artistique. Ed. Fabrice Flahutez and Miguel Egaña. Nanterre: Presses universitaires de Paris Ouest, 2013. 14960. Print.

Naum, Gellu. Liberté de dormir sur un front. Bucharest: Steaua Artei, 1937. Print. . Le Voyage Incendiaire. Bucharest: Alfa, 1936. Print.

Patry, Sylvie. "Cahier vert." Victor Brauner, écrits et correspondances 44. Print.

"La Publication des archives de Victor Brauner." Victor Brauner, écrits et correspondances 13-19. Print. 
Petreu, Marta. "Les Idées politiques de Gherasim Luca dans sa période roumaine." Synergies Roumanie 2 (2007): 57-64. Print.

Rius, Robert. Frappe de l'echo. Paris: Éditions Surréalistes, 1940. Print.

Semin, Didier. "Talismans." Victor Brauner, ou, L'enchantement surréaliste. Lausanne: Fondation de L'Hermitage, 1999. 42. Print.

—. Victor Brauner. Paris: Réunion des musées nationaux; Filipacchi, 1990. Print.

Semin, Didier, ed. Victor Brauner dans les collections du MNAM-CCI. Paris: Centre Pompidou, 1996. Print. Collections du Musée national d'art moderne.

Stella, Dominique, ed. Victor Brauner, 1903-1966. Milan: Mazzotta, 1995. Print.

Vanci-Perahim, Marina. "75 HP, la revue pictopoétique." 75 HP. Paris: J-M Place, 1993. 7-19. Print.

—. "Le Lisible et le visible: Victor Brauner de la 'picto-poésie' à la ‘hiéroglyphisation des sentiments.'” Mélusine 12 (1991): 63-70. Print.

—. "Victor Brauner: Les Débuts d'un parcours 'initiatique' (1903-1938)." Victor Brauner: Un Monde magique. Brest: Musée de Brest, 2009. 37-51. Print.

-. "Victor Brauner en Roumanie." Victor Brauner, 1903-1966. Ed. Dominique Stella. Milan: Mazzotta, 1995. 41-48. Print.

Victor Brauner: Surrealist Hieroglyphs. Houston: Menil Collection; Ostfildern-Ruit: Hatje Cantz, c2001. Print.

Victor Brauner: Un Monde magique. Brest: Musée de Brest, 2009. Print.

Voronca, Ilarie. Restriști. Bucharest: Rahova, 1923. Print.

Voronca, Ilarie, and Victor Brauner, eds. 75 HP. Bucarest: Institutul de arte grafice “Eminescu", 1924. Rpt. Paris: J-M Place, 1993. Print.

Yaari, Monique. “Le Groupe surréaliste de Bucarest entre Paris et Bruxelles: Une page d'histoire." Synergies Canada 3 (2011). Web.

<http://synergies.lib.uoguelph.ca/>. 3 March 2014.

Copyright (C) 2015 Camille Morando 